FACTA UNIVERSITATIS

Series: Philosophy, Sociology, Psychology and History Vol. 20, No 2, 2021, pp. 123 - 136

https://doi.org/10.22190/FUPSPH2102123M

Original Scientific Paper

\title{
SOCIAL SUPPORT AND RELATIONSHIP SATISFACTION AS PREDICTORS OF POSITIVE AND NEGATIVE AFFECT IN INFERTILE WOMAN DURING IVF TREATMENT
}

UDC 159.942:612.663

\section{Milica Mitrović, Jelena Opsenica Kostić, Damjana Panić}

\author{
University of Niš, Faculty of Philosophy, Department of Psychology, Serbia
}

\begin{abstract}
Infertility is a medical problem, but it can have significant consequences for mental health. Emotional problems caused by infertility are very common, so infertility can be called a life crisis. Therefore, it is very important to identify protective and risk factors that would determine the psychological adjustment to infertility. The aim of this study was to examine the differences in perceived social support, relationship satisfaction, and positive and negative affect between women undergoing IVF treatment and women who do not have fertility problems. The research also aims to examine whether perceived social support and relationship satisfaction were significant predictors of positive and negative affect in both groups. The study included 292 women - 163 who were undergoing the IVF treatment at the time of assessment and 129 without fertility problems who made up the control group. The following instruments were applied: the Multidimensional Scale of Perceived Social Support, the Relationship Satisfaction Scale, and the Serbian Inventory of Affect based on PANAS. The results show statistically significant differences between the examined groups in the level of negative affect, which is more pronounced in the group of women undergoing IVF treatment. Regarding positive affect, there is a trend of a more frequent experience of positive emotions in the women from the control group. Perceived social support and relationship satisfaction are significant predictors of both positive and negative affect for the women undergoing IVF treatment. As for the control group, the results of the regression analysis show that perceived social support and relationship satisfaction are significant predictors of negative affect, while in the case of positive affect, relationship satisfaction stands out as a significant predictor. The results indicate that perceived social support and relationship satisfaction can be important protective factors when it comes to psychological adjustment to infertility, which can serve as a guideline for mental health professionals who work with infertile couples.
\end{abstract}

Key words: infertility, IVF treatment, social support, relationship satisfaction, positive and negative affect.

Received November 14, 2020 / January June 11, 2021

Corresponding author: Milica Mitrović

University of Niš, Faculty of Philosophy, Ćirila i Metodija 2, 18000 Niš, Serbia

E-mail: milica.mitrovic@filfak.ni.ac.rs

(C) 2021 by University of Niš, Serbia | Creative Commons License: CC BY-NC-ND 


\section{INTRODUCTION}

Infertility is a common problem, which, according to the available data, affects around 48.5 million people worldwide (Verkuijlen et al. 2016). It is defined as the absence of conception after 12 months of regular unprotected sexual intercourse (ZegersHochschild et al. 2009). The life plans of most young adults include children because parenting is one of the most important needs and goals of adulthood. However, a certain number of couples, due to the inability to conceive, will need medical help to solve the problem of infertility (Boivin et al. 2007). Infertility is primarily a medical problem, but the psychological aspects are not negligible - infertility treatment can have significant consequences for both physical and mental health. In most infertile couples, in vitro fertilization (IVF) is seen as the last chance for pregnancy. Physical stress as a response to these treatments is related to the use of therapy, i.e., hormonal injections administered daily for several weeks, egg retrieval, and embryo transfer (Verhaak et al. 2004). Regarding the psychological aspect of this issue, attention is increasingly drawn both through practice and through scientific research to the psychological aspects of infertility and treatment of infertility. Thus, the emotional problems arising from infertility have been described as a crisis (Berghuis and Stanton 2002). Studies show that the stress experienced by infertile women is more intense than in men who have the same problem (Epstein and Rosenberg 2005; Wichman et al. 2011). In a study by Sundby et al. (2007), two in three women describe infertility as the worst and most stressful experience in life, while men approach this problem differently by describing it as something disappointing but not devastating (Greil et al. 1988). These results are not surprising given that infertility in women affects their experience of self and gender identity, i.e., it is accompanied by a feeling of inadequacy and emptiness because motherhood is an important part of a woman's identity and her social role (Greil et al. 2011). Compared to the control group, infertile women are more likely to experience higher levels of distress (Fekkes et al. 2003; Monga et al. 2004). The most common reactions to this type of distress are anger, guilt, low self-esteem, sexual dysfunction, shock (Burns 2007). After the review of research results and literature, De Berardis et al. (2014) concluded that 25 to $60 \%$ of people with infertility problems report psychiatric symptoms, with anxiety and depression being significantly higher in this group compared to fertile controls.

When considering psychological reactions to infertility, it should be kept in mind that infertility diagnosis and treatment is not a short-term process, i.e., there are many infertility treatment phases. Each of these phases has its specifics. Denial, sadness, fear, mistrust, and even hostility are common reactions to the infertility diagnosis (Pasch et al., 2002). Before starting the IVF treatment, most couples struggle with infertility for years (Mazure and Greenfeld 1989), which means that they are under chronic stress (Verhaak et al. 2004), in a highly uncontrollable situation. That is the reason why some authors (e.g., Domar et al. 1993) equate this stress with stress associated with other serious medical conditions like cancer. Research results show that most couples who start the IVF procedure are psychologically well adjusted (Anderheim et al. 2005; Edelmann et al. 1994; Newton et al. 1990). Moreover, it was determined that before the start of the IVF procedure, there is no difference in the level of negative emotions - anxiety and depression, between women who have and do not have this problem (Domar et al. 1993; Stanton et al. 1992). This may be due to the enthusiasm and high expectations of the treatment (Malina and Pooley 2017). However, immediately after starting the IVF 
procedure, emotional problems appear in a certain number of people (Edelmann and Connolly 2000). Compared to men, women show a higher level of negative emotions during the entire course of the IVF treatment (Eugster and Vingerhoets 1999; Salvatore et al. 2001). Most couples claim that the phase of waiting for results after embryo transfer is the most stressful phase, one which usually lasts 14 days (Boivin and Lancastle 2010; Edelmann and Connolly 2000; Ying et al. 2015).

\subsection{Protective factors in IVF treatment}

The psychological response and adjustment to the IVF procedure are determined by both risk and protective factors (Rockliff et al. 2014). Some of the established protective factors are acceptance of the situation and optimism (Verhaak et al. 2005), social support (Martins et al. 2012; Verhaak et al. 2005), problem-focused coping (Hynes et al. 1992; Verhaak et al. 2004), secure attachment style (Lowyck et al. 2009). Social support is associated with lower levels of anxiety and depression (Lechner et al. 2007; Slade et al. 2007; Verhaak et al. 2005), as well as lower levels of infertility stress (Schmidt et al. 2005; Slade et al. 2007). The results of the study by Martins et al. (2011) indicate the importance of social support in helping women deal with infertility treatment. The authors investigated the importance of partner, family, and friend support, and each proved to be important for better adaptation to treatment. Examining social support in infertile women, Jestrović and Mihić (2020) pointed out that women who participated in this research singled out the received social support from their closest ones as very prominent. The most prominent is the support of a significant other, then family, and finally friends. A regression analysis singled out family and friends' support as significant predictors of reduced infertility stress, while the support of a significant other does not make a significant unique contribution to the prediction of infertility stress, regardless of the highest prevalence of this type of support.

One of the most important social support roles is to provide a "safe environment" that would allow a person to speak openly about their feelings and concerns (Zakowski et al. 2004), so it is clear why this factor is very important for psychological adjustment to infertility treatment. However, in their research, Mindes et al. (2003) found that it often happens that people who deal with an infertility problem receive infertility-specific unsupportive responses from their social environment, which are in a positive correlation with poor psychological adjustment at the time. Rooney and Domar (2018) claim that although the infertility problem is very common, many women who experience it do not share their stories with family members or friends, thus increasing their psychological vulnerability. The results of a qualitative study conducted by Ying et al. (2015) show that infertile couples receive social support, but that some of them are ambivalent about it. Namely, some respondents claim that they feel guilty about the support provided by their parents. Moreover, some respondents hide their problems from their friends and relatives to avoid unintentionally useless comments and the additional stress caused by them. Some even feel regret that they shared some information about the treatment with others. Schmidt et al. (2005) did not find a connection between stress and keeping infertility a secret in either women or men. Regarding social support, these authors distinguish two types of sharing information with others - sharing only formal information and opening up to others in terms of talking about both formal information and emotional reactions to infertility. The first strategy was shown to be associated with higher infertility stress 
compared to the second strategy. Based on the results of their research, Wong et al. (2015) conclude that assessing perceived social support of people during infertility assessment and treatment is very important because it can help identify people who are at an increased risk of psychological distress.

Partnership and marriage can be considered another protective factor when it comes to psychological reaction and adjustment to the IVF treatment (Schmidt 2009). Studies show that the quality of marital relationships is important for happiness and well-being, as well as for frequent family and communication problems (Kohler 2005; Ren 1997; Bradbury et al. 2000). When it comes to infertile couples, it has been observed that there is significant variability in how they are affected by this problem and how it affects their relationship (Dunkel-Schetter and Lobel 1991, as cited in Pasch et al. 2002). Qualitative studies show that the infertility problem can strengthen a marriage and bring partners closer (Greil et al. 1988; Schmidt 1996, as cited in Schmidt 2006). According to the results of their study, Ying et al. (2015) conclude that infertile women emphasize the importance of sharing feelings with a partner and being supported by their partner for the subjective well-being and quality of the relationship. The results of the study by Holter et al. (2006) also show that couples undergoing IVF or ICSI report that treatment has had a positive effect on their relationship. Moreover, the divorce rate is lower in this group of respondents (17\%) compared to the general population (around 25-30\%) (Wischmann et al. 2012). However, the authors of some studies obtained to the opposite results. For example, some infertile couples experience sexual dysfunction, dissatisfaction in marriage, and social withdrawal (Lee and Sun 2000). It was found that these couples believe that both their marriage quality and marital satisfaction are at a lower level compared to couples who do not have infertility problems (Wright et al. 1991). It has also been shown that women, after being diagnosed with infertility and during treatment, rate their marital and sexual relationships more negatively than men (Newton et al. 1999; Monga et al. 2004). Wang et al. (2007) compared three groups of respondents respondents undergoing the IVF treatment, respondents in the process of ICSI procedure, and fertile controls. The results show that the first two groups have a less stable marriage compared to the third. Šakotić-Kurbalija et al. (2018) came to results that indicate a lower degree of marital satisfaction and a lower degree of marital stability in infertile women compare to the control group (women who do not have fertility problems). However, the authors emphasize that both groups of women perceive their marital relationship as having good quality and as stable, so that when considering the differences obtained, there is no mention of dissatisfaction and instability. The impact of an infertility problem on a relationship is determined by certain factors. Thus, if partners differ from each other in terms of the desire to become parents, or it is a case of only male or only female sterility, this situation can lead to frequent conflicts and misunderstandings between partners (Kuivasaari-Pirinen 2013). Given that most studies emphasize the importance and contribution of social support and marital satisfaction for psychological adjustment to infertility and treatment of infertility, we wanted to examine the existence of possible differences in perceived social support, relationship satisfaction, and positive and negative affect between women who are undergoing IVF treatment and women who do not have fertility problems. Moreover, this research aims to examine whether perceived social support and relationship satisfaction are significant predictors of positive and negative affect in both groups of women. 


\section{METHOD}

\subsection{Sample}

This study involved 163 women (mean age $=35.58 ; \mathrm{SD}=5.04$ ) who were undergoing IVF treatment at the time of testing and 129 women (mean age $=34.37 ; \mathrm{SD}=4.94$ ) who were in the control group (292 in total). The criteria for inclusion in the control group were as follows: that the woman has a child or children conceived naturally and that in the last six months she has not been exposed to a stress of greater intensity (e.g., loss of a loved one, diagnosis of a severe, chronic or fatal disease, job loss, etc.). The average duration of infertility treatment for the group of women undergoing the IVF procedure is 5.46 years $(\mathrm{SD}=3.65)$. As for the reason for starting the IVF treatment, $15.9 \%$ of them state male infertility, $27.6 \%$ female infertility, $17.2 \%$ mentioned both male and female infertility, and $39.3 \%$ state that there is no medical reason or it is unknown. The average relationship duration in the (current) relationship for the group undergoing the IVF procedure is 9.26 years $(\mathrm{SD}=4.61)$, while the average duration of the current relationships in the control group is 10.98 years $(\mathrm{SD}=5.47)$.

\subsection{Instruments}

The Relationship Satisfaction Scale (RS Scale; Røysamb et al., 2014) is used to assess general (partner) relationship satisfaction. The scale consists of ten items, and the respondents are supposed to state the level of agreement with the statement on the sixpoint Likert scale. A higher score on the scale indicates a higher level of relationship satisfaction. Some of these items are: "I have a close relationship with my spouse/partner", "My partner is generally understanding", "I have been lucky in my choice of a partner". Cronbach's alpha coefficient of this scale in a subsample of women undergoing the IVF treatment is $\alpha=.82$, while for the control group it is $\alpha=.92$.

The Multidimensional Scale of Perceived Social Support (MSPSS; Zimet et al. 1988) is intended to assess perceived social support. It consists of 12 items divided into three subscales: family support, friend support, and significant other support, but the total score on the scale is also used. The respondent gives answers on a seven-point Likert scale expressing the level of agreement with an item. In this study, we used only the total score on the scale. The reliability of the scale for the group of women undergoing the IVF treatment is $\alpha=.93$, while the reliability of the scale in the control group is $\alpha=.91$.

The Serbian Inventory of Affect based on PANAS (SIAB-PANAS; Mihić et al., 2014) is a translation and adaptation of the Positive and Negative Affect Schedule PANAS (Watson et al. 1988). This inventory is intended to assess positive and negative affectivity. It consists of 20 adjectives, which make up two subscales - one subscale measures positive and the other negative emotions. The respondents were asked to use the five-point Likert scale in order to describe how often they have experienced the described feeling in the last month. The reliability of the subscale of positive affectivity in a group of women undergoing the IVF treatment is $\alpha=.92$, while Cronbach's alpha coefficient of the subscale of negative affectivity on this subsample is $\alpha=.89$. The reliability of the positive affectivity subscale in the control group is $\alpha=.85$, while the reliability of the negative affectivity subscale is $\alpha=.90$. 


\subsection{Procedure and Statistical Data Analysis}

Before assigning tests and questionnaires, all of the respondents signed informed consent, i.e., they were informed about the objectives of the research, the way the data are going to be used, data confidentiality, as well as their rights during the testing process (e.g., the possibility of withdrawing from the study), and agreed to participate in the research.

Women undergoing IVF treatment filled in the questionnaires at the "Spebo Medical" Special Hospital for Infertility Treatment in Leskovac $(\mathrm{N}=68)$ and online $(\mathrm{N}=95)$ using the website of the Chance for Parenthood association [Šansa za roditeljstvo]. The control group also filled out questionnaires online on the Facebook page Chat for Moms from Nis [Ćaskalište za mame iz Niša].

This research study was approved by the Ethics Committee of the Department of Psychology at the Faculty of Philosophy in Nis.

The SPSS package was used for data analysis. In order to examine differences between the groups in the level of perceived social support, relationship satisfaction and positive and negative affect, the Student's t-test was used. Pearson's correlation coefficient was used to identify the correlation between the variables. A linear regression analysis (Enter method) was used to examine the contribution of predictors (Perceived social support and Relationship satisfaction) in the prediction of criteria (Positive and Negative Affect).

\section{RESULTS}

\subsection{Descriptive statistics}

Table 1 Descriptive measures

\begin{tabular}{lccrcccr}
\hline Variables & & $M$ & \multicolumn{1}{c}{$S D$} & Min & Max & \multicolumn{1}{c}{$S k$} & \multicolumn{1}{c}{ Ku } \\
\hline \multirow{2}{*}{ Perceived social support } & IVF group & 66.63 & 14.01 & 20 & 80 & -.90 & .53 \\
& Control group & 69.12 & 12.41 & 23 & 84 & -1.27 & 2.11 \\
Relationship satisfaction & IVF group & 50.79 & 9.02 & 18 & 60 & -1.18 & 1.15 \\
& Control group & 49.22 & 10.61 & 10 & 60 & -1.64 & 2.77 \\
Positive affect & IVF group & 34.86 & 7.75 & 11 & 50 & -.30 & -.33 \\
& Control group & 36.47 & 6.01 & 16 & 49 & -.72 & .73 \\
Negative affect & IVF group & 25.90 & 7.71 & 12 & 49 & .49 & -.15 \\
& Control group & 22.16 & 7.75 & 10 & 46 & .85 & .52 \\
\hline
\end{tabular}

Note: $M=$ mean value, $S D=$ standard deviation,

Min $=$ minimum, $\operatorname{Max}=$ maximum, $S k=$ Skewness, $K u=$ Kurtosis

\subsection{Differences between groups in the examined variables}

After studying the differences in the examined variables between the groups, the results have shown statistically significant differences in Negative affect, which is more pronounced in women undergoing IVF treatment. When it comes to Positive affect, women in the control group have higher scores, but the identified difference is near the level of statistical significance $(p=.053)$. Thus, the results show that Negative affect is more pronounced in women undergoing IVF treatment, while there is a trend of more frequent experience of Positive affect in the control group. Differences in Perceived social support and Relationship satisfaction between the surveyed groups were not found. 
Table 2 Differences in the examined variables between the women undergoing the IVF treatment and the control group (Student t test)

\begin{tabular}{lcccrcccc}
\hline Variables & & $N$ & $M$ & \multicolumn{1}{c}{$S D$} & $d f$ & $t$ & $p$ & $d$ \\
\hline \multirow{2}{*}{ Perceived social support } & IVF group & 163 & 66.63 & 14.01 & \multirow{2}{*}{290} & -1.59 & .114 & \\
& Control group & 129 & 69.12 & 12.41 & & & & \\
\multirow{2}{*}{ Relationship satisfaction } & IVF group & 163 & 50.79 & 9.02 & 290 & 1.36 & .175 & \\
& Control group & 129 & 49.22 & 10.61 & & & & \\
Positive affect & IVF group & 163 & 34.86 & 7.75 & 290 & -1.94 & .053 & .23 \\
\multirow{2}{*}{ Negative affect } & Control group & 129 & 36.47 & 6.01 & & & & \\
& IVF group & 163 & 25.90 & 7.71 & 20 & \multirow{2}{*}{4.09} & .000 & .48 \\
\hline
\end{tabular}

Note: $N=$ number of subjects, $M=$ mean value, $S D=$ standard deviation,

$t=$ Student's t test, $p=$ statistical significance, $d=$ effect size

\subsection{Regression analysis}

Before performing the regression analysis, the correlation between the variables was examined. The results of the correlation analysis are shown in Table 3.

Table 3 Correlation between variables in both groups of women (Pearson's correlation coefficient)

\begin{tabular}{lllllllll}
\hline & \multicolumn{3}{c}{ IVF group } & \multicolumn{5}{c}{ Control group } \\
\cline { 2 - 8 } Variables & 1 & 2 & 3 & 4 & 1 & 2 & 3 & 4 \\
\hline 1. Perceived social support & - & & & & - & & & \\
2. Relationship satisfaction & $.28^{* *}$ & - & & & $.48^{* *}$ & - & & \\
3. Positive affect & $.34^{* *}$ & $.27^{* *}$ & - & & $.26^{* *}$ & $.23^{* *}$ & - & \\
4. Negative affect & $-.26^{* *}$ & $-.28^{* *}$ & $-.44^{* *}$ & - & $-.33^{* *}$ & $-.33^{* *}$ & $-.51^{* *}$ & - \\
\hline \multicolumn{2}{c}{ Note: ${ }^{* *}$ The mean difference is significant at the .01 level. }
\end{tabular}

The results shown in Table 3 indicate that there are statistically significant correlations between all examined variables for both groups.

Table 4 Multiple regression analysis: Perceived social support and Relationship satisfaction as predictors of Positive affect (Enter procedure)

\begin{tabular}{|c|c|c|c|c|c|c|}
\hline \multirow[b]{2}{*}{ Predictors } & \multicolumn{3}{|c|}{ IVF group } & \multicolumn{3}{|c|}{ Control group } \\
\hline & $\beta$ & $p$ & Model summary & $\beta$ & $p$ & Model summary \\
\hline Perceived social support & .308 & .000 & $\begin{array}{l}R=.402 \\
R^{2}=.162\end{array}$ & .194 & .152 & $\begin{array}{l}R=.288 \\
R^{2}=.083\end{array}$ \\
\hline Relationship satisfaction & .188 & .016 & $\begin{array}{l}F(2,161)=14.776 \\
p=.000\end{array}$ & .140 & .047 & $\begin{array}{l}F(2,128)=5.719 \\
p=.004\end{array}$ \\
\hline
\end{tabular}

Note: $R=$ multiple correlation coefficient, $R^{2}=$ multiple correlation coefficient of determination, $F=\mathrm{F}$ statistic, $p=$ statistical significance, $\beta=$ regression coefficient.

The results of the regression analysis shown in Table 4 indicate that in the group of women undergoing the IVF treatment, both Perceived social support and Relationship 
satisfaction represent statistically significant predictors of Positive affect, with Perceived social support making a greater partial contribution to criterion prediction. The results show that the model explains $16 \%$ of the variance of the criteria. In regards to the control group, in this case Relationship satisfaction stands out as a significant predictor of Positive affect, with the model explaining only $8 \%$ of the variance of the criteria.

Table 5 Multiple regression analysis: Perceived social support and Relationship satisfaction as predictors of Negative affect (Enter procedure)

\begin{tabular}{|c|c|c|c|c|c|c|}
\hline \multirow[b]{2}{*}{ Predictors } & \multicolumn{4}{|c|}{ IVF group } & \multicolumn{2}{|c|}{ Control group } \\
\hline & $\beta$ & $p$ & Model summary & $\beta$ & $p$ & Model summary \\
\hline Perceived social support & -.211 & & $\begin{array}{l}R=.350 \\
R^{2}=.122\end{array}$ & -.219 & .020 & $\begin{array}{l}R=.386 \\
R^{2}=.149\end{array}$ \\
\hline Relationship satisfaction & -.226 & .005 & $\begin{array}{l}\mathrm{F}(2,161)=10.718 \\
p=.000\end{array}$ & -.230 & .015 & $\begin{array}{l}\mathrm{F}(2,128)=11.050 \\
p=.000\end{array}$ \\
\hline
\end{tabular}

Note: $R=$ multiple correlation coefficient, $R^{2}=$ multiple correlation coefficient of determination, $F=\mathrm{F}$ statistic, $p=$ statistical significance, $\beta=$ regression coefficient.

As seen from Table 5, in the subsample of women undergoing the IVF treatment, Perceived social support and Relationship satisfaction are significant predictors of Negative affect. The model explains $12 \%$ of the variance of the criteria. Similar results were obtained in the control group as well. Perceived social support and Relationship satisfaction have been shown to be significant predictors of Negative affect here as well, with the model explaining $14.9 \%$ of the variance of the criteria. The individual contributions of the predictors $(\beta)$ are similar in both subsamples and are in a negative correlation with the criterion.

\section{DISCUSSION}

Infertility is primarily a medical problem, which in some cases has considerable psychological consequences with the characteristics of a life crisis (Berghuis and Stanton, 2002). For that reason, it is very important to identify factors that would to some extent "determine" psychological adjustment to infertility. With this in mind, in this study, we examined the differences in perceived social support, relationship satisfaction, positive and negative affect between women who were undergoing IVF treatment at the time of testing, and women who did not have fertility problems. Moreover, the contribution of perceived social support and relationship satisfaction in predicting positive and negative affect in both groups included in this research was examined.

Comparing the group of women undergoing the IVF treatment and the control group, no differences were found in the level of perceived social support and relationship satisfaction. There is a statistically significant difference regarding Negative affect, which is more pronounces in the group of women undergoing the IVF treatment. The result obtained was expected given the results of previous studies. When considering the difference obtained, it should be borne in mind that women who participated in this study and who have an infertility problem were treated for infertility for 5.46 years on average, which is a fairly long period of exposure to stress. Moreover, it is important to point out that all women at the time of testing were undergoing the IVF treatment. Before 
beginning the IVF procedure, most couples treat infertility for years, with IVF being their last chance to have children (Mazure and Greenfeld 1989; Verhaak et al. 2004). Infertility stress is therefore compared to the long-term stress that accompanies a chronic illness (Domar et al. 1993). Furthermore, the results of research by Edelmann and Connelly (2000) show that emotional problems occur immediately after starting the IVF procedure. Given all the above, it is not surprising that the difference was observed between the studied groups. Finally, if we look at the SIAB-PANAS items and scores (Mihić et al. 2014), we can say that women undergoing the IVF treatment compared to the control group more often feel upset, afraid, hostile, ashamed, nervous, distressed, etc. which is also congruent with previous studies (Burns 2007; Fekkes et al. 2003; Monga et al. 2004). Therefore, it could be said that the obtained results suggest that the IVF treatment may be the reason for the more frequent occurrence of negative emotions.

When it comes to positive affect, the results obtained indicate that there is a difference between these two groups. However, from the aspect of the findings that are near the level of statistical significance $(p=.053)$, and due to the small difference in effect size ( $d$ $=.23$ ) in relation to positive affectivity, we can talk about the trend of more frequent experience of positive emotions (enthusiasm, pride, focus, interest, etc.) in the control group. Given that more pronounced differences were expected between the examined groups, this result is encouraging because it supports the fact that the IVF treatment does not necessarily lead to a predominant negative affect and that women who undergo this procedure do manage to find a source of positive emotions in other areas of life. Studies show that during intensely stressful experiences, both positive and negative emotions occur at the same time, i.e., that stressful events can also be associated with positive emotions. Positive and negative emotions are independent, that is, they do not exclude one another (Folkman 2008; Larsen and McGraw 2011). Moreover, it has been shown that in the case of patients suffering from chronic diseases (HIV, cancer, heart failure) that involve a constant threat to health and life, positive emotions can play a significant adaptive role (according to Kroemeke 2016). In this regard, we reiterate the statement made by Domar et al. (1993) that the stress caused by infertility diagnosis and treatment can be equated with the stress that accompanies a chronic disease. Thus, it can be said that the results obtained are consistent with the results of previous studies, which indicate that when experiencing a stressful event people can experience both positive and negative emotions. These results are also encouraging given the adaptive role of positive emotions in highly stressful situations.

Guided by the idea of the importance of identifying some protective factors, from the aspect of psychological adjustment to infertility, we examined the contribution of perceived social support and relationship satisfaction in predicting positive and negative affect in both groups of women included in this study. The results show that in the group of women undergoing the IVF treatment, perceived social support and relationship satisfaction are significant predictors of positive affect and that the model explains $16 \%$ of the criteria variance. Perceived social support makes a slightly larger independent contribution to the prediction of the criteria. The results are congruent with the results of previous studies on the importance of these factors for psychological adjustment to infertility (e.g., Martins et al. 2012; Verhaak et al. 2005; Ying et al. 2015). However, it is more important to compare these results with the results obtained for the control group. Namely, the results show that perceived social support is not a significant predictor of positive affect. However, relationship satisfaction is a significant predictor, but at the very borderline of statistical significance. The model explains only $8 \%$ of the variance. In this group, perceived social support and 
relationship satisfaction are not particularly important for experiencing positive emotions. This group of women may find sources of positive affect in some other areas of life. It should be kept in mind that the control group has a more pronounced positive affect and that the criterion for being in the control group is the absence of higher levels of stress in the last six months (while respondents undergoing the IVF treatment are currently exposed to intense stress). This indicates that the result obtained was expected, but more importantly, it indicates the importance of social support and relationship satisfaction for the emotional status of infertile women during the IVF procedure.

When it comes to negative affect, perceived social support and relationship satisfaction are significant predictors of negative affect in women undergoing IVF. The model explains $12 \%$ of the criteria variance, with the predictors negatively correlating with the criterion. The obtained results are congruent with the results of previous studies (Lechner et al. 2007; Slade et al. 2007; Varhaak et al. 2005). Similar results were obtained in the control group as well. Here, too, perceived social support and relationship satisfaction are significant predictors of negative affect, which make a negative correlation with the criterion. The model explains $14.9 \%$ of the variance of the criteria. The results obtained suggest that social support and satisfaction with partner relationship in women are seen as protective factors, which play a role in reducing negative affect regardless of the situation.

After reviewing the results obtained in connection with the partner relationship, we can say that the findings are in line with the results of previous studies on the importance of the quality of marital relations for happiness and well-being (Kohler et al. 2005; Ren 1997; Bradbury et al. 2000). Social support has proven to be very important for the emotional status of women undergoing IVF treatment. The importance of social support is noted by Wong et al. (2015) in the sense that a perceived level of social support can be a significant indicator of the increased risk of psychological distress during infertility assessment and treatment. In the control group, social support does not contribute to positive affect but contributes to the reduction of negative affect, which may indicate a specific effect of social support in this group of women.

\section{CONCLUSION AND LIMITATIONS}

It is necessary to verify these results on a larger sample, which would include respondents of both genders, with the analysis of a larger number of variables that could represent significant factors for psychological adjustment to infertility and infertility treatment. The low number of predictors of the emotional status of the respondents included in this research represents its greatest limitation.

The results obtained represent important guidelines for experts whose field of expertise is psychological counseling and psychotherapy for people with infertility problems. Efforts on improving a relationship and social support networks could be one of the goals of psychological treatment, with the purpose of preserving mental health in situations highly challenging for the adaptive capacities of most people.

Acknowledgement: We would like to thank the Special Hospital for the Treatment of Infertility in Leskovac "Spebo Medical" and the Association "Chance for Parenthood" for their help in conducting this research. 


\section{REFERENCES}

Anderheim, Lisbeth, Herborg Holter, Christina Bergh, and Anders Möller. "Does psychological stress affect the outcome of in vitro fertilization?" Human Reproduction 20 (2005): 2969-2975.

Berghuis, James P., and Annette L. Stanton. “Adjustment to a Dyadic Stressor: A Longitudinal Study of Coping and Depressive Symptoms in Infertile Couples Over an Insemination Attempt”. Journal of Consulting and Clinical Psychology 70 (2002): 433-438.

Boivin, Jacky, Laura Bunting, John A. Collins, and Karl G. Nygren. "International estimates of infertility prevalence and treatment-seeking: Potential need and demand for infertility medical care". Human Reproduction 22 (2007): 1506-1512.

Boivin, Jacky, and Deborah Lancastle. "Medical waiting periods: Imminence, emotions and coping". Women's Health 6 (2010): 59-69.

Bradbury, Thomas N., Frank D. Finchman, and Steven R. Beach. "Research on the nature and determinants of marital satisfaction: A decade in review". Journal of Marriage and Family 62 (2000): 964-980.

Burns, Linda H. "Psychiatric aspects of infertility and infertility treatments". Psychiatric Clinics of North America 30 (2007): 689-716.

De Berardis, Domenico, Monica, Mazza, Stefano Marini et al. "Psychopathology, emotional aspects and psychological counselling in infertility: a review". La Clinica Terapeutica 165 (2014): 163-169.

Domar, Alice D., Patricia C. Zuttermeister, and Richard Friedman. "The psychological impact of infertility: A comparison with patients with other medical conditions". Journal of Psychosomatic Obstetrics \& Gynecology 14 (1993): 45-52.

Edelmann, Robert J., Kevin J. Connolly, and Helen Bartlett. "Coping strategies and psychological adjustment of couples presenting for IVF”. Journal of Psychosomatic Research 38 (1994): 355-364.

Edelmann, Robert J., and Kevin J. Connolly. "Gender differences in response to infertility and infertility investigations: Real or illusory”. British Journal of Health Psychology 5 (2000): 365-375.

Epstein, Yakov M., and Helene S. Rosenberg. "Depression in primary versus secondary infertility egg recipients". Fertility and Sterility 83 (2005):1882-1884.

Eugster, Antje, and Andrianus J. J. M. Vingerhoets. "Psychological aspects of in vitro fertilization: A review". Social Science \& Medicine 48 (1999): 575-589.

Fekkes, Minne, Simone Buitendijk, Gijsbert H. W.Verrips, et al. "Health-related quality of life in relation to gender and age in couples planning IVF treatment". Human Reproduction 18 (2003): 1536-1543.

Folkman, Susan. "The case for positive emotions in the stress process". Anxiety, Stress, \& Coping 21 (2008): 3-14.

Greil, Arthur L., Thomas A. Leitko, and Karen L. Porter. "Infertility: His and Hers". Gender and Society 2 (1988): 172-199.

Greil, Arthur, Julia McQuillan, and Kathleen Slauson-Blevins. "The Social Construction of Infertility". Sociology Compass 5 (2011): 736-746.

Holter, Herborg, Lisbeth Anderheim, Christina Bergh, and Anders Möller. "First IVF treatment - Short-term impact on psychological well-being and the marital relationship". Human Reproduction 21 (2006): 3295-3302.

Hynes, Gloria J., Victor J. Callan, Deborah J. Terry, and Cynthia Gallois. "The psychological well-being of infertile women after a failed IVF treatment: The effects of coping". British Journal of Medical Psychology 65 (1992): 269-278.

Jestrović, Jovana i Ivana Mihić. "Socijalna podrška i stres povodom neplodnosti: značajnost različitih izvora podrške". Primenjena psihologija 13 (2020): 169-189.

Kohler, Hans-Peter, Jere R. Behrman, and Axel Skytthe. "Partner + children = happiness? An assessment of the effect of fertility and partnerships on subjective well-being in Danish twins". Population and Development Review 31 (2005): 407-445.

Kroemeke, Aleksandra. "Changes in well-being after myocardial infarction: Does coping matter?" Quality of Life Research 25 (2016):2593-2601.

Kuivasaari-Pirinen, Paula. The Pathway from Infertility to Motherhood through Assisted Reproductive Technology (ART) (PhD diss.). University of Eastern Finland, 2013.

Larsen, Jeff T., and Peter A. McGraw. "Further Evidence for Mixed Emotions". Journal of Personality and Social Psychology 100 (2011): 1095-1110.

Lechner, Lilian, Catherine Bolman, and Ankie van Dalen. "Definite involuntary childlessness: Associations between coping, social support and psychological distress". Human Reproduction 22 (2007): 288-294.

Lee, Tsorng-Yeh, and Guang-Huan Sun. "Psychosocial response of Chinese infertile husbands and wives". Archives of Andrology 45 (2000): 143-148.

Lowyck, Benedicte, Patrick Luyten, Jozef Corveleyn, Thomas D’Hooghe, Evelien Buyse, and Koen Demyttenaere. "Well-being and relationship satisfaction of couples dealing with an in vitro fertilization/ intra cytoplasmic 
sperm injection procedure: A multilevel approach on the role of self-criticism, dependency, and romantic attachment". Fertility and Sterility 91 (2009): 387-395.

Malina, Alicja, and Julie A. Pooley. "Psychological consequences of IVF fertilization - Review of research". Annals of Agricultural and Environmental Medicine 24 (2017): 554-558.

Martins, Mariana V., Brennan D. Peterson, Vasco M. Almeida, and Maria E. Costa. "Direct and indirect effects of perceived social support on women's infertility-related stress”. Human Reproduction 26 (2011): 2113-2121.

Martins, Mariana V., Brennan D. Peterson, Patricio Costa, Maria E. Costa, Rikke Lund, and Lone Schmidt. "Interactive effects of social support and disclosure on fertility-related stress". Journal of Social and Personal Relationships 30 (2012): 371-388.

Mazure, Carolyn M., and Dorothy A. Greenfeld. "Psychological studies of in vitro fertilization/embryo transfer participants". Journal of Assisted Reproduction and Genetics 6 (1989): 242-256.

Mihić, Ljiljana, Zdenka Novović, Petar Čolović, and Snežana Smederevac. "Serbian Adaptation of the Positive and Negative Affect Schedule (PANAS): Its Facets and Second-order Structure". Psihologija 47 (2014): 393-414.

Mindes, Erica J., Kathleen M. Ingram, Wendy Kliewer, and Cathy A. James. "Longitudinal analyses of the relationship between unsupportive social interactions and psychological adjustment among women with fertility problems". Social Science \& Medicine 56 (2003): 2165-2180.

Monga, Manoj, Bogdan Alexandrescu, Seth E. Katz, Murray Stein, and Theodore Ganiats. "Impact of infertility on quality of life, marital adjustment, and sexual function". Urology 63 (2004): 126-130.

Newton, Christopher, Matthew T. Hearn, and Albert A. Yuzpe. "Psychological assessment and follow-up after in vitro fertilization: Assessing the impact of failure". Fertility and Sterility 54 (1990): 879-886.

Newton, Christopher R., Wendy Sherrard, and Irene Glavac. "The Fertility Problem Inventory: Measuring perceived infertility-related stress". Fertility and Sterility 72 (1999): 54-62.

Pasch, Lauri A., Christine Dunkel-Schetter, and Andrew Christensen. "Differences between husbands' and wives' approach to infertility affect marital communication and adjustment". Fertility and Sterility 77 (2002): 1241-1247.

Ren, Xinhua S. "Marital Status and Quality Relationships: The Impact of Health Perception". Social Science and Medicine 44 (1997): 241-249.

Rockliff, Helen E., Stafford L. Lightman, Emily Rhidian, Heather Buchanan, Uma Gordon, and Kavita Vedhara. "A systematic review of psychosocial factors associated with emotional adjustment in in vitro fertilization patients". Human Reproduction Update 20 (2014): 594-613.

Rooney, Kristin L., and Alice D. Domar. "The relatipnship between stress and infertility". Dialogues in Clinical Neuroscience 20 (2018): 41-47.

Røysamb, Espen, Joar Vitters $\varnothing$, Kristian Tambs. "The relationship satisfaction scale - Psychometric properties". Norsk Epidemiologi 24 (2014): 187-194.

Salvatore, Paola, Simonetta Gariboldi, Ada Offidani, Francesco Coppola, Mario Amore, and Carlo Maggini. "Psychopathology, personality, and marital relationship in patients undergoing in vitro fertilization procedures". Fertility and Sterility (2001):1119-1125.

Schmidt, Lone. "Infertility and assisted reproduction in Denmark". Danish Medical Bulletin 53 (2006): 390-417.

Schmidt, Lone. "Social and psychological consequences of infertility and assisted reproduction - What are the research priorities?”. Human Fertility 12 (2009): 14-20.

Schmidt, Lone, Bjørn E. Holstein, Ulrik Christensen, and Jacky Boivin. "Communication and coping as predictors of fertility problem stress: Cohort study of 816 participants who did not achieve a delivery after 12 months of fertility treatment". Human Reproduction 20 (2005): 3248-3256

Slade, Pauline, Claire O'Neill, John A. Simpson, and Hany Lashen. "The relationship between perceived stigma, disclosure patterns, support and distress in new attendees at an infertility clinic". Human Reproduction 22 (2007): 2309-2317.

Stanton, Annette L., Howard Tennen, Glenn Affleck, and Richard Mendola. "Coping and adjustment to infertility". Journal of Social and Clinical Psychology 11 (1992): 1-13.

Sundby, Johanne, Lone Schmidt, Kristin Heldaas, Solveig Bugge, and Tom Tanbo. "Consequences of IVF among women: 10 years post-treatment”. Journal of Psychosomatic Obstetrics \& Gynecology 28 (2007): $115-120$.

Šakotić-Kurbalija, Jelena, Biljana Trifunović i Marija Zotović. "Značaj bračne neplodnosti za doživljaj kvaliteta bračnog odnosa i potencijal za razvod kod žena". U Društveno, porodično i lično značenje neplodnosti: Implikacije za planiranje podrške parovima, urednice Ivana Mihić i Marija Zotović, 49-69. Novi Sad: Filozofski fakultet u Novom Sadu, 2018.

Verhaak, Christianne M., Jesper M. J. Smeenk, van Agnes Minnen, and Floris W. Kraaimaat. "Neuroticism, preattentive and attentional biases towards threat, and anxiety before and after a severe stressor: A prospective study". Personality and Individual Differences 36 (2004): 767-778 
Verhaak, Christianne M., Jesper M. J. Smeenk, Agnes Minnen, Jan A. M. Kremer, and Floris W. Kraaimaat. "A longitudinal, prospective study on emotional adjustment before, during and after consecutive fertility treatment cycles". Human Reproduction 20 (2005): 2253-2260.

Verkuijlen, Jolijn, Christianne Verhaak, Willianne L. Nelen, Jack Wilkinson, and Cindy Farquhar. "Psychological and educational interventions for subfertile men and women". Cochrane Database of Systematic Reviews 3 (2016): CD011034.

Wang, Kehua, Juan Li, John X. Zhang, Lihong Zhang, Jianchun Yu, and Ping Jiang. "Psychological characteristics and marital quality of infertile women registered for in vitro fertilization-intracytoplasmic sperm injection in China". Fertility and Sterility 87 (2007): 792-798.

Watson, D., Lee A. Clark, and Auke Tellegen. "Development and validation of brief measures of positive and negative affect: The PA PANAS scales”. Journal of Personality and Social Psychology 54 (1988): 1063-1070.

Wichman, Christina L., Shawna L. Ehlers, Scott E. Wichman, Amy L. Weaver, and Charles Coddington. "Comparison of multiple psychological distress measures between men and women preparing for in vitro fertilization". Fertility and Sterility 95 (2011): 717-721.

Wischmann, Tewes, Kristina Kõrge, Horst Scherg, Thomas Strowitzki, and Rolf Verres. "A 10-year follow-up study of psychosocial factors affecting couples after infertility treatment". Human Reproduction 27 (2012): 3226-3232.

Wong, Jacqueline M., Angela K. Lawson, Michael Lanham, Senait Fisseha, and Molly B. Moravek. "A cry for help: The relationship between perceived social support and quality of life in infertility patients". Fertility and Sterility 104 (2015): 360e.

Wright, John, Claude Duchesne, Stephane Sabourin, Francois Bissonnette, Johanne Benoit, and Yvan Girard. "Psychosocial distress and infertility: Men and women respond differently". Fertility and Sterility 55 (1991): 100-108.

Ying, Li-Ying, Lai H. Wu, and Alice Y Loke. "The experience of Chinese couples undergoing in vitro fertilization treatment: Perception of the treatment process and partner aupport". PloS one 10 (2015): e.013969.

Zakowski, Sandra G., Alona Ramati, Carla Marton, Peter Johnson, and Robert Flanigan. "Written emotional disclosure buffers the effects of social constraints on distress among cancer patients". Health Psychology 23 (2004): 555-563.

Zegers-Hochschild, Fernando, et al. "The international committee for monitoring assisted reproductive technology (ICMART) and the world health organization (WHO) revised glossary on ART terminology, 2009”. Human Reproduction 24 (2009): 2683-2687.

Zimet, Gregory D., Nancy W. Dahlem, Sara G. Zimet, and Gordon K. Farley. "The multidimensional scale of perceives social support”. Journal of Personality Assessment 52 (1988): 30-41.

\section{SOCIJALNA PODRŠKA I ZADOVOLJSTVO PARTNERSKIM ODNOSOM KAO PREDIKTORI POZITIVNOG I NEGATIVNOG AFEKTA KOD ŽENA TOKOM VTO TRETMANA}

Neplodnost predstavlja medicinski problem, koji može imati značajne posledice po mentalno zdravlje. Emocionalni problemi nastali kao posledica neplodnosti su veoma česta pojava, pa se neplodnost može nazvati životnom krizom. Iz tog razloga veoma je značajno identifikovati zaštitne faktore $i$ faktore rizika koji bi odredili psihološko prilagođavanje na neplodnost. Cilj ovog istraživanja jeste ispitati postojanje razlika u percipiranoj socijalnoj podršci, zadovoljstvu partnerskim odnosom i pozitivnom i negativnom afektu između žena koje su u VTO postupku i žena koje nemaju ovu vrstu problema. Takođe, istraživanje je imalo za cilj da ispita da li su percipirana socijalna podrška i zadovoljstvo partnerskim odnosom značajni prediktori pozitivnog i negativnog afekta u obe grupe ispitanica. U istraživanju su učestvovale 292 žene - 163 žene koje su u trenutku testiranja bile uključene u VTO tretman i 129 žena bez problema sa plodnošću, koje su činile kontrolnu grupu. Korišćeni su sledeći instrumenti: Multidimenzionalna skala percipirane socijalne podrške, Skala zadovoljstva partnerskim odnosom i Srpski inventar afekta baziran na PANAS. Rezultati pokazuju da statistički značajne razlike između ispitivanih grupa postoje u izraženosti negativnog afekta, koji je izraženiji u grupi žena u VTO postupku. Kada je reč o pozitivnom afektu uočava se postojanje trenda učestalijeg prisustva pozitivnih emocija kod ispitanica iz kontrolne grupe. U grupi žena u VTO postupku percipirana socijalna podrška i zadovoljstvo partnerskim 
odnosom predstavljaju značajne prediktore kako pozitivnog tako i negativnog afekta. U kontrolnoj grupi rezultati regresione analize pokazuju da su percipirana socijalna podrška i zadovoljstvo partnerskim odnosom značajni prediktori negativnog afekta, dok se u slučaju pozitivnog afekta kao značajan prediktor izdvaja zadovoljstvo partnerskim odnosom. Rezultati ukazuju da percipirana socijalna podrška i zadovoljstvo partnerskim odnosom mogu biti značajni zaštitni faktori kada je u pitanju psihološka adaptacija na neplodnost, što može poslužiti kao smernica u radu stručnjaka u oblasti mentalnog zdravlja, koji rade sa parovima sa ovim problemom.

Ključne reči: neplodnost, VTO tretman, socijalna podrška, zadovoljstvo partnerskim odnosom, pozitivni i negativni afekt. 